\title{
Teacher Professional Development In Sindh Through Nacte: Analytical Study
}

\author{
Ms Nusrat Ali, P.Hd Scholor, Federal Urdu University of Arts, Sciences \& Technology \\ Dr Kamal Haider, Assistant Professor, Federal Urdu University of Arts, Sciences \& Technology
}

\begin{abstract}
Wisdom is not deemed stagnant in this dynamic global environment. If the situation evolves, new awareness and people's capacity to survive in society are needed. Teachers should be successful in today's society and learn new skills and expertise. The same was emphasized by (Holmes, 2005) in the words that "there is no stagnation in the level of knowledge as it changes after every moment and one has to keep abreast accordingly." Professional Development helps enhance teachers' teaching methods to apply knowledge and skill that will bring improvement in performance on the job. (Mizell, 2010) One should pursue involuntarily to learning new ideas and concepts. The study is based on the NACTE and its accreditation standards on the challenges faced by Teacher Education Institutions in ensuring the quality of the teacher education program in Pakistan. The study is based on mixed-method research design following sequential triangulation techniques adopting the pragmatic paradigm of research. Data collection instruments used in this study was in-depth surveys and a structured questionnaire from teacher educators of public sector universities of Sindh. The results and recommendations are discussed at the end of the study. Research shows that students' achievements are evaluated through teaching quality and school leadership, and these two can be made as effective as possible if educational knowledge and practices and its implementation is continually expanded. (Kenneth Leithwood, 2004). For an efficient and productive educational system, maintaining the quality of teacher preparation is thus imperative. Significant and continuous efforts are needed to increase the standard of our country's teacher education on priority bases.
\end{abstract}

Keywords: NACTE, Professional Development, Quality, Self-Management, Stakeholder

$\begin{array}{lll}\text { Received: 07.12.2020 Accepted: } 16.01 .2021 & \text { Published: 04.02.2021 }\end{array}$

\section{INTRODUCTION}

Teacher Quality has always been a significant concern. However, the idea of accreditation of teacher training programs is a recent scenario in Pakistan owing to a consistency system for maintaining the performance of teacher education. For the standard of academic programs offered by educational institutions, accreditation in Teacher Education institutions are expected. The smooth and effective operation and growth of an open and democratic society depend on a quality higher education system. In Higher Education, social expectations of contact and participation in society need to be developed and provided. The heterogeneous students have compelled the establishment of structures to ensure the quality of their education and programs, particularly in higher education. The competence and the level of teaching of the instructor are closely related to the norm of the classroom. In the education of society, a teacher plays a critical and essential role. It is rightly said that the education system does not meet the level of skill of their teacher. Hence it is important for an effective and efficient education system to maintain the quality of teacher education. Significant and steady efforts are needed on a priority basis in our country to enhance the standard of teacher education. This is because only little consideration is given to the consistency dimensions of teacher preparation programs, contributing to the training of teachers who are perceived both as superior in terms of material and instructional practices. (National Education Policy 1998-2010, p47).

There are a variety of programs bringing in professional development starting from in commission training to external organized ones, both for public and personal sectors; however, there are many challenges connected to them. These programs are attended by around $20-25 \%$ of the entire population of educators. These programs are extended to the institution within the sort of workshops conducted by the attendees of those Professional Development programs however the most concern is that the reluctance and sluggishness on the part of teachers which fails the aim. A number of the programs alienate instead of invigorating or succour the educators. These sorts of programs are a hindrance to the implementation and 
application within the classroom. The educators emphasize that the Professional development programs must address the day to day challenges of scholars and should not be 'One- Size-Fit-All' that targets the sizable amount of educators from different schools of various levels with different levels of scholars. (Aslam, 2013).

Professional development must also cater to educators' varying levels of motivation, interest, knowledge and skill. The rationale behind the research on this problem is to spot the effective Professional Development Programs, the explanations for its requirement, the causes for his or her non-availability, the impact on students' learning through untrained and trained teachers and other related issues. This research hopes to become an eye fixed opener and albeit it brings a touch change, it'll be a serious success as every small step may be a move towards an enormous change.

NACTE is legalized to assess the standards of teacher education organizations provided by all universities and colleges of the public and private sectors, including institutions providing HEC-approved affiliated/collaborated teacher training services to international universities.

Both graduate and post-graduate education institutions must be accredited in compliance with the rules. NACTE established a Conceptual Frame Work which is included Curriculum, Assessment, Physical Infrastructure and Learning \&Human Resources, Finance and Management, Scholarship and Research and Community Links.

A minimum criterion of accreditation is The Conceptual Frame Work. The seven principles are listed as optimal proposals for long-term progress preparation. The criteria represent various elements and each aspect is further separated into observable measures. The signs reflect what the assessment of the software wants to know. Following the open accreditation process and processes to maintain the quality of teacher education through the accreditation process by NACTE.

\section{LITERATURE REVIEW}

In educating society, the teacher plays the most critical and vital role. It is a fact that no education system suits the teacher's level of competency. Therefore, for maintaining the quality of education for teachers there is a need for an effective and productive education system. Government of Pakistan seems to have been highly influenced by its counterparts in the USA in recent years. As in the United States, the requirements were compatible with the same information, responsibilities, and provisions (Chung and Kim, 2010,) Teacher Education Program Accreditation NACTE established Programs and Education (ESD) (Mirza, 2015) Professional Development helps to promote teaching practices to apply expertise and skills to improve job performance (Mizell, 2010). Professional development does not exist for tertiary education teachers in Pakistan. Vogrinc, J., JURISEVIC, M., \& Devetak, I. (June 2010.)

Teaching practice is an important part of initial teacher education. We must evaluate the quality of pedagogical practices in initial training for teacher trainees, as these modules train future teachers in their career. Ahmed Abdullah, N., and Mirza Sultana, M. (2020). Teacher training programs are necessary to meet the teacher development objectives for overall the world. Sustainability Education (EFS) aims at empowering and trying to prepare instructors for a more sustainable future through education. Merritt, A., Merritt, E. And Archambault, L. And L. P (2019).

The quality of trained and professional teachers lies in their on-the-job experience and abilities. The priorities and overall national development over the past 20 years have been the improvement of teaching education and the teaching profession (Czerniawski et al. 2018; McInerney et al, 2018). The efficacy of the curriculum is improved by in-service preparation for instructors, trainers, and academic managers with the help of teaching techniques (khatoon, 2008). Various factors have been involved in the quality and success of teachers in Pakistan, including the absence of low educational qualifications, lack of continuing professional development and recruiting on non-merit. Higher education institutions (HEIs) are now evolving dramatically because of the advancement of higher education, global competition, innovations and improved job efficiency. These innovations influence the requirements of stakeholders. Higher education institutions have been challenged by the enormous growth in HIEs and students to ensure that their students earn the required qualifications for graduates (Oliver \& Jorre de St Jorre 2018).

Maxwell (2017).argues that education students do not leave schools and colleges with an indisputable understanding of what the general public, their peers and their calls expect of them. As van der nest (2012) points out, competent development for educators involves any movement that develops teachers' insights and skills and enables them to believe in their mindset and the way they influence academics 
education to improve the character of teaching and learning, However, amongst the literature on teacher education in Pakistan, most of it points out the issues and challenges only (Ali, 2011; Gopang, 2016, p.1-14). Highlighting factors such as the quantitative expansion of teacher education over qualitative expansion to be one of the main reasons that teachers lack basic knowledge of how to teach.

\section{Objectives of The Study}

The main objectives of the study are as under

- The impact of awareness that Professional Development is the need to keep in pace with the advancement.

- To see the improvement of the Assessment and Evaluation process of Prospective Teacher and Teacher Educator areas in a broad spectrum.

- Identify the Community Links, corporate organizations or philanthropists.

\section{Hypothesis}

The research hypotheses are as under.

There is no significant difference between o Public and Private \& Accredited and Not Accredited in NACTE with regards to:

- To see the impact of Professional Development has played a significant role in teacher education of Sindh.

- To compare the improvement of Assessment and Evaluation process of Prospective Teacher and Teacher Educator areas in a broad spectrum.

- To evaluate the Community links are mostly funded and run by corporate organization or philanthropist.

\section{RESEARCH METHODOLOGY}

The researcher has used mixed-method research designs to find out the answers to research questions. The population of this study includes all Teacher Education Institutions/ Faculty of Education offering graduate and post-graduate-level courses in Sindh that are duly recognized by Higher Education Commission Pakistan. Considering the total population size 10 Teacher Education Institutions (Private\& Public) and around 105faculty members. An average of 10 faculty members in each institute and 551 prospective teachers' approximate 55 prospective teachers in each institute. The researcher used a purposive sampling technique.

\section{Research Instrument}

For the purpose of research, two custom-made research instruments were developed;

- One was a Self-Administered Questionnaire for Teacher Educators for selected teacher education institutions. It consists of 55 close-ended questions with the simple categorization of responses SA=Strongly Agree, A=Agreed=Undecided, A=Disagree, SDA=Strongly Disagree. The Second Questionnaire for Prospective Teachers. This questionnaire also consists of 45close ended questions with a simple categorization of responses $\mathrm{SA}=$ Strongly Agree, $\mathrm{A}=$ Agreed=Undecided, $\mathrm{A}=\mathrm{D}$ isagree, SDA=Strongly Disagree, \& One open-ended query became part of the survey prejudice control questionnaire to collect accurate opinions of prospective teachers.

- For qualitative analysis interview was conducted for TEIs heads for the purpose of NACTE performance and overview about the misconception of quality and the role of the accreditation process.

\section{Data Analysis}

To test the hypothesis, using chi-square. 
H1. To see the impact of Professional Development has played a significant role in teacher education of Sindh

\begin{tabular}{|c|c|c|c|c|c|c|}
\hline \multicolumn{6}{|c|}{ Option * Sector Cross tabulation } & \multirow{3}{*}{ P-Value } \\
\hline & & & \multicolumn{2}{|l|}{ Sector } & \multirow{2}{*}{ Total } & \\
\hline & & & Public & Private & & \\
\hline \multirow{10}{*}{ Option } & \multirow{2}{*}{ Strongly Agree } & Count & 1732 & 746 & 2478 & \multirow{12}{*}{0.001} \\
\hline & & $\%$ of Total & $19.6 \%$ & $8.5 \%$ & $28.1 \%$ & \\
\hline & \multirow{2}{*}{ Agree } & Count & 2594 & 1644 & 4238 & \\
\hline & & $\%$ of Total & $29.4 \%$ & $18.6 \%$ & $48.1 \%$ & \\
\hline & \multirow{2}{*}{ Undecided } & Count & 668 & 542 & 1210 & \\
\hline & & $\%$ of Total & $7.6 \%$ & $6.1 \%$ & $13.7 \%$ & \\
\hline & \multirow{2}{*}{ Disagree } & Count & 238 & 402 & 640 & \\
\hline & & \% of Total & $2.7 \%$ & $4.6 \%$ & $7.3 \%$ & \\
\hline & \multirow{2}{*}{$\begin{array}{l}\text { Strongly } \\
\text { Disagree }\end{array}$} & Count & 128 & 122 & 250 & \\
\hline & & \% of Total & $1.5 \%$ & $1.4 \%$ & $2.8 \%$ & \\
\hline \multirow{2}{*}{\multicolumn{2}{|c|}{ Total }} & Count & 5360 & 3456 & 8816 & \\
\hline & & \% of Total & $60.8 \%$ & $39.2 \%$ & $100.0 \%$ & \\
\hline
\end{tabular}

\section{Applied chi-square test}

The p-value of the chi-square test is 0.001 which is less than 0.05 , therefore we reject Ho and conclude that there is a significant difference in opinion of public and private prospective teachers with regards to the awareness of Professional Development has been significant in the improvement and advancement of teacher education in Sindh.

\begin{tabular}{|c|c|c|c|c|c|c|}
\hline \multicolumn{6}{|c|}{ Option * NACTE Cross Tabulation } & \multirow[b]{3}{*}{ P-Value } \\
\hline & & & \multicolumn{2}{|l|}{ NACTE } & \multirow[b]{2}{*}{ Total } & \\
\hline & & & $\begin{array}{l}\text { Accredit } \\
\text { ed }\end{array}$ & \begin{tabular}{|l|} 
Not \\
Accredit \\
ed \\
\end{tabular} & & \\
\hline \multirow{10}{*}{ Option } & \multirow{2}{*}{ Strongly Agree } & Count & 1738 & 7440 & 22478 & \multirow{12}{*}{0.001} \\
\hline & & \% of Total & $\mid 19.7 \%$ & $8.4 \%$ & $28.1 \%$ & \\
\hline & \multirow{2}{*}{ Agree } & Count & 2987 & 1251 & 42238 & \\
\hline & & \% of Total & $33.9 \%$ & $14.2 \%$ & $448.1 \%$ & \\
\hline & \multirow{2}{*}{ Undecided } & Count & 960 & 250 & 1210 & \\
\hline & & \% of Total & $10.9 \%$ & $2.8 \%$ & $13.7 \%$ & \\
\hline & \multirow{2}{*}{ Disagree } & Count & 477 & 163 & 640 & \\
\hline & & \% of Total & $5.4 \%$ & $1.8 \%$ & $7.3 \%$ & \\
\hline & \multirow{2}{*}{$\begin{array}{l}\text { Strongly } \\
\text { Disagree }\end{array}$} & Count & 174 & 76 & 250 & \\
\hline & & \% of Total & $2.0 \%$ & $0.9 \%$ & $2.8 \%$ & \\
\hline \multirow{2}{*}{\multicolumn{2}{|c|}{ Total }} & Count & 6336 & 2480 & 8816 & \\
\hline & & $\%$ of Total & $71.9 \%$ & $28.1 \%$ & $100.0 \%$ & \\
\hline
\end{tabular}

\section{Applied chi-square test}

The p-value of the chi-square test is 0.001 which is less than 0.05 , therefore we reject Ho and conclude that there is a significant difference in opinion of the institution has accredited and not accredited in NACTE with regards to the awareness of Professional Development has been significant in the improvement and advancement of teacher education in Sindh. 
H-11. To compare the improvement of Assessment and Evaluation process of Prospective Teacher and Teacher Educator areas in a broad spectrum.

\begin{tabular}{|c|c|c|c|c|c|c|}
\hline \multicolumn{6}{|c|}{ Option * Sector Cross Tabulation } & \multirow{3}{*}{ P-Value } \\
\hline & & & \multicolumn{2}{|l|}{ Sector } & \multirow{2}{*}{ Total } & \\
\hline & & & Public & Private & & \\
\hline \multirow{10}{*}{ Option } & \multirow{2}{*}{ Strongly Agree } & Count & 251 & 63 & 314 & \multirow{12}{*}{0.001} \\
\hline & & \% of Total & $22.8 \%$ & $5.7 \%$ & $28.5 \%$ & \\
\hline & \multirow{2}{*}{ Agree } & Count & 299 & 168 & 4667 & \\
\hline & & \% of Total & $27.1 \%$ & $15.2 \%$ & $42.4 \%$ & \\
\hline & \multirow{2}{*}{ Undecided } & Count & 68 & 77 & 145 & \\
\hline & & \% of Total & $6.2 \%$ & $7.0 \%$ & $13.2 \%$ & \\
\hline & \multirow{2}{*}{ Disagree } & Count & 35 & 97 & 132 & \\
\hline & & \% of Total & $3.2 \%$ & $8.8 \%$ & $12.0 \%$ & \\
\hline & \multirow{2}{*}{$\begin{array}{l}\text { Strongly } \\
\text { Disagree }\end{array}$} & Count & 17 & 27 & 44 & \\
\hline & & \% of Total & $1.5 \%$ & $2.5 \%$ & $4.0 \%$ & \\
\hline \multirow{2}{*}{\multicolumn{2}{|c|}{ Total }} & Count & 670 & 432 & 1102 & \\
\hline & & \% of Total & $60.8 \%$ & $39.2 \%$ & $100.0 \%$ & \\
\hline
\end{tabular}

\section{Applied chi-square test}

The p-value of the chi-square test is 0.001 which is less than 0.05 , therefore we reject Ho and conclude that there is a significant difference in opinion of public and private prospective teachers with regards to the assessment and evaluation and management process and monitor Teacher Prospective and Teacher Educator areas are varied and have a broad spectrum.

\begin{tabular}{|c|c|c|c|c|c|c|}
\hline \multicolumn{6}{|c|}{ Option * NACTE Cross tabulation } & \multirow{3}{*}{ P-Value } \\
\hline & & & \multicolumn{2}{|l|}{ NACTE } & \multirow{2}{*}{ Total } & \\
\hline & & & Yes & No & & \\
\hline \multirow{10}{*}{ Option } & \multirow{2}{*}{ Strongly Agree } & Count & 203 & 111 & 314 & \multirow{12}{*}{0.001} \\
\hline & & \% of Total & $18.4 \%$ & $10.1 \%$ & $28.5 \%$ & \\
\hline & \multirow{2}{*}{ Agree } & Count & 331 & 136 & 467 & \\
\hline & & \% of Total & $30.0 \%$ & $12.3 \%$ & $42.4 \%$ & \\
\hline & \multirow{2}{*}{ Undecided } & Count & 119 & 26 & 145 & \\
\hline & & \% of Total & $10.8 \%$ & $2.4 \%$ & $13.2 \%$ & \\
\hline & \multirow{2}{*}{ Disagree } & Count & 109 & 23 & 132 & \\
\hline & & \% of Total & $9.9 \%$ & $2.1 \%$ & $12.0 \%$ & \\
\hline & \multirow{2}{*}{$\begin{array}{l}\text { Strongly } \\
\text { Disagree }\end{array}$} & Count & 30 & 14 & 44 & \\
\hline & & \% of Total & $2.7 \%$ & $1.3 \%$ & $4.0 \%$ & \\
\hline \multirow{2}{*}{\multicolumn{2}{|c|}{ Total }} & Count & 7992 & 310 & 1102 & \\
\hline & & \% of Total & $71.9 \%$ & $28.1 \%$ & $100.0 \%$ & \\
\hline
\end{tabular}

\section{Applied chi-square test}

The p-value of the chi-square test is 0.001 which is less than 0.05 , therefore we reject Ho and conclude that there is a significant difference in opinion of the institution has accredited and not accredited in NACTE with regards to the assessment and evaluation and management process and monitor Teacher Prospective and Teacher Educator areas are varied and have a broad spectrum. 
H-III. To evaluate the Community links are mostly funded and run by corporate organization or philanthropist.

\begin{tabular}{|c|c|c|c|c|c|c|}
\hline \multicolumn{6}{|c|}{ Option * Sector Cross tabulation } & \multirow{3}{*}{ P-Value } \\
\hline & & & \multicolumn{2}{|l|}{ Sector } & \multirow{2}{*}{ Total } & \\
\hline & & & Public & Private & & \\
\hline \multirow{10}{*}{ Option } & \multirow{2}{*}{ Strongly Agree } & Count & 108 & 41 & 149 & \multirow{12}{*}{0.001} \\
\hline & & \% of Total & $9.8 \%$ & $3.7 \%$ & $13.5 \%$ & \\
\hline & \multirow{2}{*}{ Agree } & Count & 364 & 165 & 529 & \\
\hline & & \% of Total & $33.0 \%$ & $15.0 \%$ & $48.0 \%$ & \\
\hline & \multirow{2}{*}{ Undecided } & Count & 1117 & 111 & 228 & \\
\hline & & $\%$ of Total & $10.6 \%$ & $10.1 \%$ & $20.7 \%$ & \\
\hline & \multirow{2}{*}{ Disagree } & Count & 63 & 81 & 144 & \\
\hline & & \% of Total & $5.7 \%$ & $7.4 \%$ & $13.1 \%$ & \\
\hline & \multirow{2}{*}{\begin{tabular}{|l|} 
Strongly \\
Disagree
\end{tabular}} & Count & 18 & 34 & 52 & \\
\hline & & \% of Total & $1.6 \%$ & $3.1 \%$ & $4.7 \%$ & \\
\hline \multirow{2}{*}{\multicolumn{2}{|c|}{ Total }} & Count & 670 & 432 & 1102 & \\
\hline & & $\%$ of Total & $60.8 \%$ & $39.2 \%$ & $100.0 \%$ & \\
\hline
\end{tabular}

\section{Applied chi-square test}

The p-value of the chi-square test is 0.001 which is less than 0.05 , therefore we reject Ho and conclude that there is a significant difference in opinion of public and private prospective teachers with regards to the community links are mostly funded and run by corporate organization or philanthropist.

\begin{tabular}{|c|c|c|c|c|c|c|}
\hline \multicolumn{6}{|c|}{ Option * NACTE Cross Tabulation } & \multirow{3}{*}{ P-Value } \\
\hline & & & \multicolumn{2}{|c|}{ NACTE } & \multirow{2}{*}{ Total } & \\
\hline & & & Yes & No & & \\
\hline \multirow{10}{*}{ Option } & \multirow{2}{*}{ Strongly Agree } & Count & 99 & 50 & 149 & \multirow{12}{*}{0.002} \\
\hline & & \% of Total & $9.0 \%$ & $4.5 \%$ & $13.5 \%$ & \\
\hline & \multirow{2}{*}{ Agree } & Count & 381 & 148 & 529 & \\
\hline & & \% of Total & $34.6 \%$ & $13.4 \%$ & $48.0 \%$ & \\
\hline & \multirow{2}{*}{ Undecided } & Count & 183 & 45 & 228 & \\
\hline & & \% of Total & $16.6 \%$ & $4.1 \%$ & $20.7 \%$ & \\
\hline & \multirow{2}{*}{ Disagree } & Count & 100 & 44 & 144 & \\
\hline & & $\%$ of Total & $9.1 \%$ & $4.0 \%$ & $13.1 \%$ & \\
\hline & \multirow{2}{*}{$\begin{array}{l}\text { Strongly } \\
\text { Disagree }\end{array}$} & Count & 29 & 23 & 52 & \\
\hline & & $\%$ of Total & $2.6 \%$ & $2.1 \%$ & $4.7 \%$ & \\
\hline \multirow{2}{*}{\multicolumn{2}{|c|}{ Total }} & Count & 792 & 310 & 1102 & \\
\hline & & $\%$ of Total & $71.9 \%$ & $28.1 \%$ & $100.0 \%$ & \\
\hline
\end{tabular}

\section{Applied chi-square test}

The p-value of chi-square test is 0.002 which is less than 0.05 , therefore we reject Ho and conclude that there is a significant difference in opinion of the institution has accredited and not accredited in NACTE with regards to the community links are mostly funded and run by corporate organization or philanthropist.

\section{Qualitative Analysis}

Results obtained from the interviews are discussed in the following

- First question related with quality, Majority of heads agreed the concept of quality, refers to quality with performance and achievement of students, if teachers will not academically sound, they would not be able to perform critically and quality suffers a lot. 
- The second question relates to awareness the need of accreditation of programs, most of the heads agreed that the accreditation process is necessary to for teacher education institutions but practical efforts should be made to enhance consistency\& the procedure accreditation process should be improved.

- Half of the Heads acknowledged that they see a positive change in their point of view that certain standards in our programs had already been strengthened remaining $50 \%$ still disagreed with the argument that these services need a systematic clarification.

- Majority heads accepted this statement, but some of them opposed that the need to improve NACTE efficiency, arguing that third-party evaluation is not guaranteed, but that an organizational mechanism is in force. Quality education should be given to the administrator.

\section{CONCLUSION}

- The research also concludes that despite all problems \& issues NACTE had played a profound role to developing teacher education programs, although till yet institutions adopted this process forcefully not for improving quality, but the process of accreditation bounds the institutions to develop quality standards and be implemented. On the other side, the role of NACTE increased importance day by day, and this is a very good sign for improving the quality of our teacher education programs.

- It was also observed that multiple weaknesses of some organizations did not realize that the importance of accreditation process \& they blamed that excessive work and overburdened process frustrated teachers and institutions, but the reality is that the process of accreditation control the fake programs \& it is not possible to run the program without accreditation process .this is the good sign for improved quality teacher education programs.

\section{RECOMMENDATIONS}

In this study, recommendations regarding the standard of teacher education in Pakistan were drawn.

1. A new quality framework to be established for maintaining the standard of teacher education by NACTE and the provincial department of education

2. The standards of accreditation should be formulated scientifically and the evaluation should be strictly enforced in word and deed on the indicators by the NACTE.

3. To enhance the curriculum, organization, students' learning and revision of curriculum content, analysis results of all feedback and programs must become mandatory for assessment of performance results.

4. The teaching educational institutions should be initiated among students coupled with physical resources and co-curricular programs for guidance, counselling, remedial positioning and follow-up services.

5. There should be special effort to build and enhance the community participation of organizations and engage the group in outreach projects and institutional growth.

\section{REFERENCES}

Ahmed Abdullah, N., \& Sultana Mirza, M. (2020). Evaluating Pre-Service Teaching Practice for Online and Distance Education Students in Pakistan: Evaluation of Teaching Practice. International Review of Research in Open and Distributed Learning, 21(2), 81-97.

Ali, T. (2011). Understanding how practices of teacher education in Pakistan compare with the popular theories and theories and narrative of reform of teacher education in international context. International Journal of Humanities and Social Sciences, 1(8), 208- 222.

Aslam, H. D. (2013). Analysis of professional development practices for school teachers in Pakistan: A comparative case study of public and private schools of Pakistan (Punjab). International Journal of Human Resource Studies, 3(4), 311.

Chung, H. \& Kim, H. (2010). Implementing professional standards in teacher preparation programs in the United States: Preservice teachers' understanding of teaching standards. KEDI Journal of Educational Policy, 7(2), 355-377.

Gopang, I. B. (2016). Teacher Education and Professional Development Programs in Pakistan. The International Journal of Research in Teacher Education, 7(1), 1-14. 
Holmes, M. D., Chen, W. Y., Feskanich, D., Kroenke, C. H., \& Colditz, G. A. (2005). Physical activity and survival after breast cancer diagnosis. Jama, 293(20), 2479-2486.

Khatoon, A. (2008). Impact of ADB assisted teacher training project on the quality of teacher education in Pakistan (Doctoral dissertation, INTERNATIONAL ISLAMIC UNIVERSITY ISLAMABAD, PAKISTAN).

Maxwell, B. (2017). Codes of Professional Conduct and Ethics Education for Future Teachers. Philosophical Inquiry in Education, 24(4), 323-347.

Merritt, E., Hale, A., \& Archambault, L. (2019). Changes in pre-service teachers' values, sense of agency, motivation and consumption practices: A case study of an education for sustainability course. Sustainability, 11(1), 155.

Mirza, M. S. (2015). Institutionalizing ESD standards in teacher education programs: Case of national accreditation council for teacher education, Pakistan. Applied Environmental Education \& Communication, 14(2), 97-104.

Mizell, H. (2010). Why Professional Development Matters. Learning Forward. 504 South Locust Street, Oxford, OH 45056

Oliver, B., \& Jorre de St Jorre, T. (2018). Graduate attributes for 2020 and beyond: recommendations for Australian higher education providers. Higher Education Research \& Development, 37(4), 821-836. https://doi.org/10.1080/07294360.2018.1446415

Vogrinc, J., JURISEVIC, M., \& Devetak, I. (2010, June). Ethical Aspects In Science Education Research. In XIV IOSTE Symposium. Bled, Slovenia. 